\title{
スチールフレーム方式 DEVELOPMENT OF CFRC CFRC カーテンウォール CURTAIN WALLS REINFORCED の開発 BY STEEL FRAME STRUCTURE
}

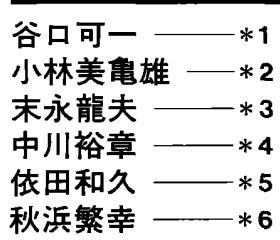
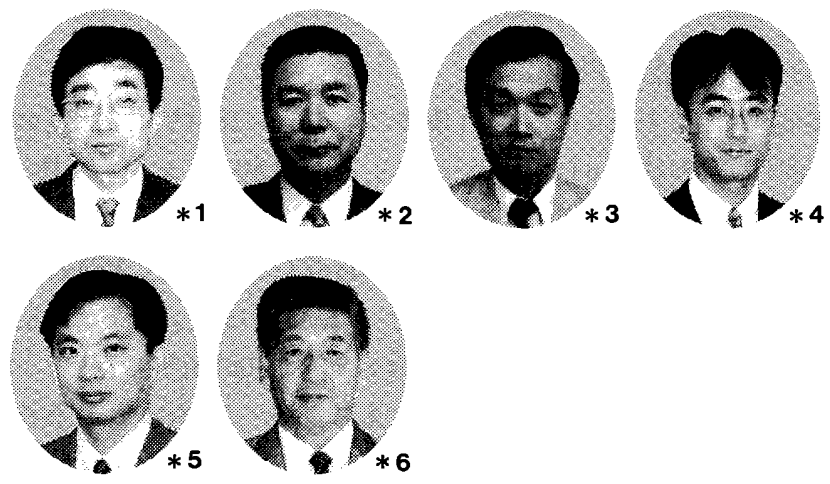

キーワード

カーテンウォール, スチールフレーム方式, 炭素織維補強コンクリート, 低収縮セ メント, 石先付け

\section{Yoshikazu TANIGUCHI \\ Mikio KOBAYASHI \\ Tatsuo SUENAGA \\ Hiroaki NAKAGAWA \\ Kazuhisa YODA \\ Shigeyuki AKIHAMA}

Taking full advantage of the Carbon Fiber Reinforced Concrete (CFRC), new steel-framed curtain wall panel with CFRC with uniform thickness and high dimensional stability without autoclave curing was developed, while conventional CFRC has been designed to have perimeter rib which leads to a complicated cross section, heavy weighted and complicated manufacturing. It was found that the new steel-framed CFRC curtain wall panel with a natural stone surface could be manufactured in practice, and confirmed to have sufficient performance whereby an application to building constructions was executed.

\section{1 はじめに}

安価なピッチ系炭素繊維が 1980 年代に製造されるようになった のに伴い, CFRC(炭素繊維補強コンクリート)の研究開発も進んで きた。CFRC は強度特性, 寸法安定性, 而久性に優れ, かつ軽量で あるという特徵を生かし, 建築二次部材の中でも特にカーテンウォ ールとしてこれまで多く使用されてきた。

CFRC製カーテンウォールが開発された当初は，カーテンウォー ル四周の断面を厚くすることにより補強したリブ方式の構造が採用 されていた。しかしながら, 勒性・強度が高いCFRCにおいては, 通常のコンクリートとは異なり薄いパネル状とすることが可能であ る。この特徵を生かして，パネルの裏面をりブではなくスチールフ レームによって補強した方式のカーテンウォールを考案した。この 方式を用いたカーテンウォールの特長は, CFRC 部分が等厚断面に なるためパネル部材内の寸法変化が均一となり，亀裂の発生防止の 点から有利であること，パネルの大型化が容易なこと, リブ方式よ りも重量が低減できることおよび型枠・配筋・製造が簡略化される ことなどが挙げられる。

一方, 従来の CFRC は, 寸法安定性確保のためにオートクレーブ 養生を行っていたために，石やラスタータイルの先付けが困難であ
Keywords :

Curtain wall, Steel frame structure, CFRC, Low-contractile cement, Granite facing
1 鹿島技術研究所 主任研究員

*2 鹿島技術研究所 専門部長

*3 鹿島技術研究所 主管研究員

*4 鹿島技術研究所 主任研究員

*5 鹿島技術研究所 研究員

6 (株)エフ・アール・シー 副社長・エ博
つた。また，スチールフレーム方式のカーテンウォールを製造する とすれば，オートクレーブ養生の後にフレームをパネルに取り付け ねばならず，大きな手間がかかるのが難点と推測された。

以上のことから，オートクレーブ養生を不要とし，石先付けを可 能とするスチールフレーム方式の CFRC製カーテンウォールを開 発することを目標に，以下に示す一連の実験研究を実施した。

\section{2 低収縮セメントを用いたCFRC の物性試験}

\section{1 試験の目的}

事前に, 低収縮セメントを用いた CFRC に関して最適と考えられ る調合を決定するために，各種の調合を検討し基礎物性試験を行っ た。その結果から決定した比重の異なる二つの調合について最終的 に物性の確認を行った。

\section{2 供試体}

\section{2.1 使用材料と CFRC の調合}

試験に使用した炭素繊維・セメント・骨材の性質を表 1〜表 3 に, CFRCの調合を表 4 に示す。

\section{2.2 練り混ぜ・成形・養生方法}

CFRCの練り混ぜにはオムニミキサを使用した。供試体は成形 後, 図 1 に示すように $40^{\circ} \mathrm{C}$ で蒸気養生を行い, 約 20 時間で脱型し, 
表 1 炭素繊維の性質

\begin{tabular}{|c|c|c|c|c|c|c|c|}
\hline \multirow{4}{*}{$\begin{array}{c}\text { 炭素䋐維 } \\
\text { の種類 }\end{array}$} & \multicolumn{3}{|c|}{ 織 維 形状 } & \multirow{4}{*}{ 比重 } & \multirow{4}{*}{$\begin{array}{c}\text { 引張強度 } \\
(\mathrm{kgf} / \\
\left.\mathrm{mm}^{2}\right)\end{array}$} & \multirow{4}{*}{$\begin{array}{c}\text { 弹性係数 } \\
(\mathrm{kgf} / \\
\left.\mathrm{mm}^{2}\right)\end{array}$} & \multirow{4}{*}{$\begin{array}{l}\text { 伸度 } \\
(\%) \\
\end{array}$} \\
\hline & 直径 & 長さ & アスペ & & & & \\
\hline & $\langle d\rangle$ & $\langle\ell\rangle$ & クト比 & & & & \\
\hline & $(\mu \mathrm{m})$ & $(\mathrm{mm})$ & $(\ell / \mathrm{d})$ & & & & \\
\hline ピッチ系 & 18.0 & 6.0 & 333 & 1.63 & 78 & $3.8 \times 10^{3}$ & 2.1 \\
\hline
\end{tabular}

表 2 セメントの性質

\begin{tabular}{|c|c|c|c|c|c|c|c|}
\hline \multirow{2}{*}{ 種類 } & \multicolumn{5}{|c|}{ 化 学成 分 (\%) } & \multicolumn{2}{|c|}{ 物理的性質 } \\
\hline & $\mathrm{S} \mathrm{i} \mathrm{O}_{2}$ & $\mathrm{All}_{2} \mathrm{O}_{3}$ & $\mathrm{Fe}_{2} \mathrm{O}_{3}$ & $\mathrm{C}$ a O & $\mathrm{SO}_{3}$ & 比重 & 比表面積 \\
\hline E収縮セ & 23 & 11 & 1 & 48 & 9 & 2.96 & $4500 \mathrm{~cm}^{2} / 8$ \\
\hline
\end{tabular}

表 3 骨材の性質

\begin{tabular}{c|c|c|c|c|c}
\hline \multirow{2}{*}{ 骨材の種類 } & \multicolumn{3}{|c|}{ 化 学 成 分 $(\%)$} & \multicolumn{2}{c}{ 物理的性質 } \\
\cline { 2 - 6 } & $\mathrm{S} \mathrm{i} \mathrm{O}_{2}$ & ${\mathrm{~A} 1_{2} \mathrm{O}_{3}}$ & その他 & 比重 & 粒径 $(\mu \mathrm{m})$ \\
\hline 粉 末 硅 石 & 95.0 & 2.2 & 2.8 & 2.7 & $0 \sim 80$ \\
\hline シラスバルーン & 67.0 & 14.0 & 19.0 & 1.0 & $0 \sim 150$ \\
\hline
\end{tabular}

表 $4 \mathrm{CFRC}$ の調合

\begin{tabular}{|c|c|c|c|c|c|}
\hline 調合 & $\begin{array}{c}\text { 水セメ } \\
\text { ント比 } \\
(\%)\end{array}$ & $\begin{array}{c}\text { 計画緎維 } \\
\text { 混入率 } \\
\left(V_{0} \text { \%) }\right.\end{array}$ & \begin{tabular}{|c|}
$\frac{h}{h}$ 材・セ \\
メント比 \\
$(\mathrm{S} / \mathrm{C})$
\end{tabular} & 骨材の種類 & $\begin{array}{l}\text { 混和剂 } \\
\text { の種類 }\end{array}$ \\
\hline A & 47.3 & \multirow[t]{2}{*}{2.0} & 0.254 & 粉末硅石 & \multirow{2}{*}{ 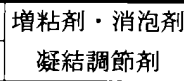 } \\
\hline B & 73.3 & & 0.427 & シラスバルーン・粉末硅石 & \\
\hline
\end{tabular}

※ S : 骨材 (重量), C : セメント（重量）

※ 調合 $\mathrm{B}$ のシラスバルーンと粉末硅石との割合は，重量比で $1: 2.09$

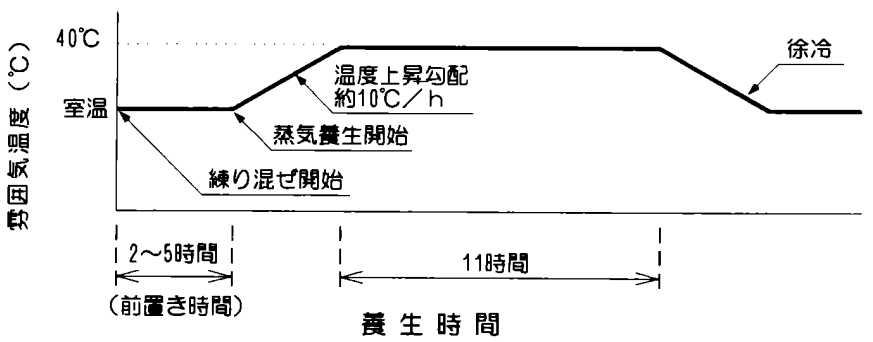

図1 蒸気養生の温度履歴

その後 $20^{\circ} \mathrm{C} ・ 60 \% \mathrm{RH}$ 条件室に試験まで静置した。

\section{2.3 供試体の形状}

圧縮試験の供試体の形状は, $50 \phi \times 100 \mathrm{~mm}$, 曲げ試験および長さ 変化試験の供試体の形状は $40 \times 40 \times 160 \mathrm{~mm}$ とした。

\section{3 試験方法}

\section{3.1 フレッシュ CFRC}

フレッシュ CFRCの特性を確認するために, CFRCの練り上り 直後にフロー試験を JIS R 5201 に, 単位容積重量試験を JIS A 1116 に準じてそれぞれ行った。なお実績繊維混入率は, CFRCの単 位容積重量と各材料の比重から計算で求めた。

\section{3.2 硬化した CFRC}

硬化した CFRC の特性を把握するために圧縮・曲げ・長さ変化試 験を行った。

a. 圧縮試験：100 ton オートグラフ試験機を用い, クロスヘッド スピード $0.5 \mathrm{~mm} /$ 分の変位制御で, 材令 28 日にて試験を行った。

b. 曲げ試験：2 ton オートグラフ試験機を用い,クロスヘッドス ピード $2.0 \mathrm{~mm} /$ 分の変位制御で，材令 28 日にて試験を行った。な

お，載荷方式はスパン $100 \mathrm{~mm}$ の中央集中載荷とした。

c. 長さ変化試験：JIS A 1129 (コンパレーター万法)に準じて行
つた。供試体を脱型後直ちに基長を測定し，その後所定材令にて測 定を行った。な扮測定期間中, 供試体を $20^{\circ} \mathrm{C} \cdot 60 \% \mathrm{RH}$ 条件室に静 置した。

\section{4 結果と考察}

\section{4.1 フレッシュ CFRC}

試験結果を表 5 に示す。

表 5 フレッシュ CFRCの特性

\begin{tabular}{c|c|c|c|c}
\hline 調合 & $\begin{array}{c}\text { 実績繊維混入率 } \\
(\text { Vol \% })\end{array}$ & $\begin{array}{c}\text { 練り上がり温度 } \\
\left({ }^{\circ} \mathrm{C}\right)\end{array}$ & フロー値 & $\begin{array}{c}\text { 単位容積重量 } \\
(\mathrm{kg} / \ell)\end{array}$ \\
\hline $\mathrm{A}$ & 2.07 & 31.5 & 161 & 1.78 \\
\hline $\mathrm{B}$ & 2.03 & 27.0 & 159 & 1.58 \\
\hline
\end{tabular}

\section{4.2 硬化した CFRC}

強度試験結果を表 6 に示す。A 調合は B 調合に比べて圧縮強度お よび曲げ強度が約 1.6 倍大きかったが，これは水セメント比の違い による影響が大きいと思われる。

長さ変化試験結果を図 2 に示す。両調合の CFRC とも, 初期材令 にて膨張し, 材令 5 日前後にてそのピークをむかえた。このように 初期に膨張を起こすのは, 低収縮セメントが水和の初期にエトリン ガイトを生成し, 膨張を起こすためである。なお $\mathrm{A}$ 調合は, $\mathrm{B}$ 調合 に比べて膨張量が大きく，また材令 20 週に扔ける収縮量は小さい。 一方, 従来の $\mathrm{CFRC} は 20^{\circ} \mathrm{C} \cdot 60 \% \mathrm{RH}$ 条件室に静置した場合に,

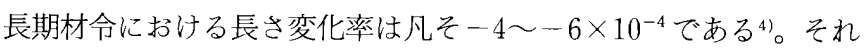
に対して低収縮セメントを用いた CFRCも, 図 2 からわかるように 長期材令に扔ける長さ変化率は $-4 \sim-6 \times 10^{-4}$ にほほ収まると思 われる。したがって, 低収縮セメントを用いた CFRCの長さ変化率 (乾燥収縮率) はオートクレーブ養生を行った従来の CFRC とほほ 同等であると言える。

表 6 CFRC の強度試験結果

\begin{tabular}{c|c|c|c}
\hline 調合 & 気乾比重 & $\begin{array}{c}\text { 圧樎強度 } \\
\left(\mathrm{kgf} / \mathrm{cm}^{2}\right)\end{array}$ & $\begin{array}{c}\text { 曲活強度 } \\
\left(\mathrm{kgf} / \mathrm{cm}^{2}\right)\end{array}$ \\
\hline $\mathrm{A}$ & 1.66 & 319 & 166 \\
\hline $\mathrm{B}$ & 1.29 & 196 & 99 \\
\hline
\end{tabular}

※ 強度は 3 体の供試体の平均値

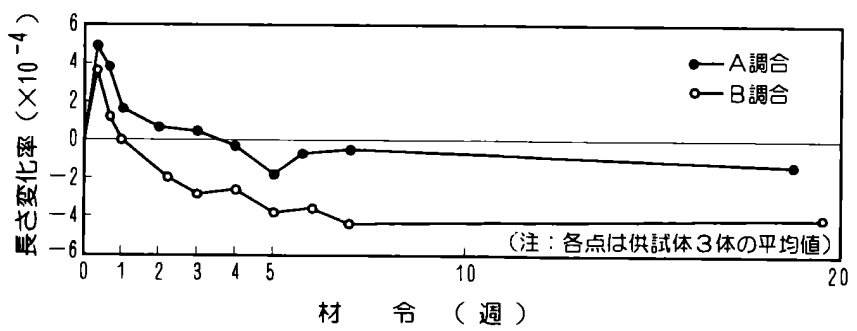

図 2 長さ変化率と材令との関係

\section{3 シアコネクター引き抜き実験}

\section{1 実験の目的}

CFRC カーテンウォールは, 従来の PC(プレキャストコンクリー ト）カーテンウォールに比べて薄肉である。石先付け仕上げの場合 には, シアコネクターの形状で CFRCの最小厚みが制限される。本 実験では CFRCの厚みを $60 \mathrm{~mm}$ として, これに対応した小型のシ 
アコネクターを 2 種類試作し, 引き抜き実験を行いその耐力を確認

した。

3.2 実験の要因と水準

実験の要因と水準を表 7 に示す。

表 7 シアコネクター引き抜き実験の要因と水準

\begin{tabular}{|c|c|}
\hline 要因 & 水準 \\
\hline シアコネクターの形状 & i）2重バネ型 ii）ハンガー型 \\
\hline & i ）稲田石(国産) ii ）ピンクポリーノ(スペイン産) \\
\hline 石材 (花岡岩) の種類 & iii）カパオポニート(プラジル産) \\
\hline & iv） ベルファースト(南アフリカ産) \\
\hline 石材 の 厚 み & i) $25 \mathrm{~mm}$ ii ) $35 \mathrm{~mm}$ \\
\hline C F R C の調合 & i) $A$ 調合 ii) $B$ 調合 \\
\hline
\end{tabular}

\section{3 供試体}

実験に用いた 2 種類のコネクターの形状・寸法を図 3 に示す。

石材の裏面は通常は裏面処理材により処理されるが, 本実験では 石材と CFRCの界面での付着が切断された場合を想定して, 厚さ $0.15 \mathrm{~mm}$ のビニールシートを敷き込んだ。

供試体は, 型枠底面に, コネクターを取り付けた石材をセットし, その上に CFRC を打設して成形した。供試体の形状・寸法を図 4 に 示す。

1 次養生は図 1 に示す方法で行った。その後, 供試体を実験まで 屋内に静置した。
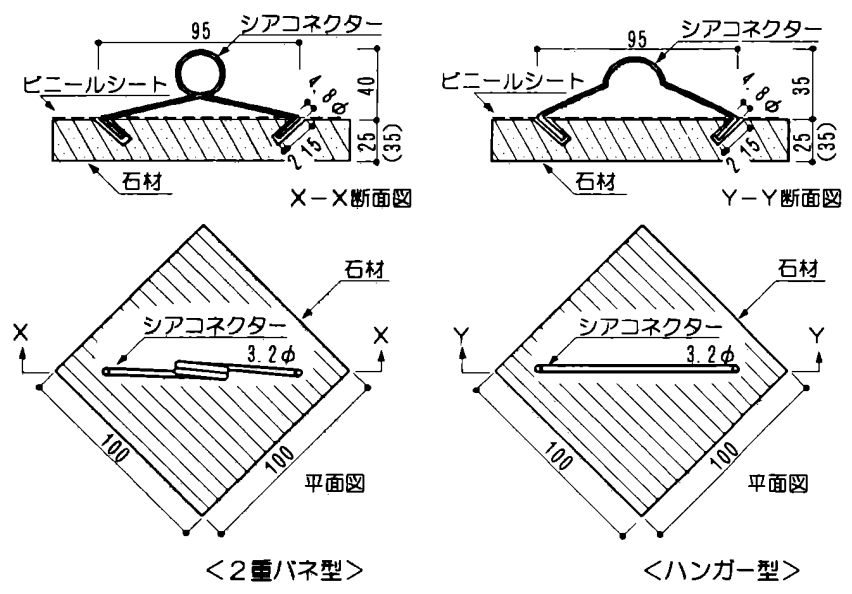

図 3 シアコネクターの形状・寸法

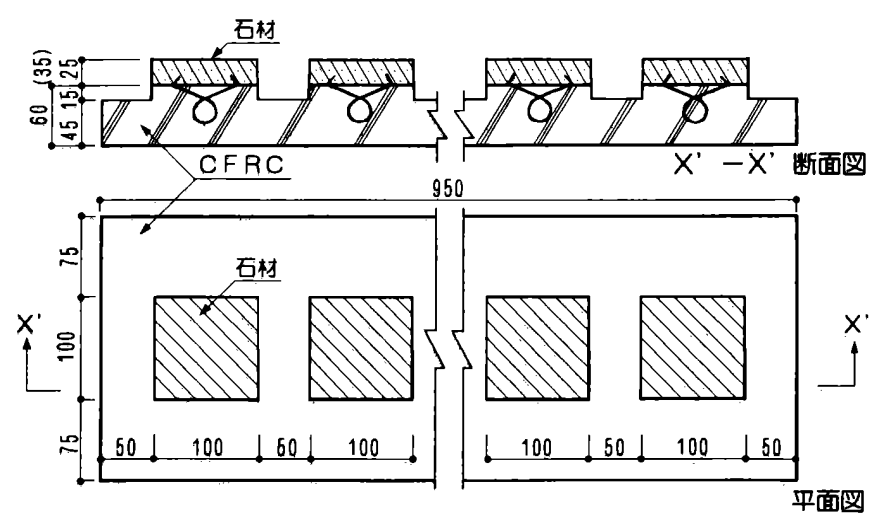

図 4 シアコネクター引き抜き実験の供試体の形状・寸法

\section{4 実験方法}

実験は，石材に鋼製のアタッチメント（100×100×10 mm）を接 着剂で貼り，建研式接着力試験機（最大能力 2 ton）を使用して, CFRCの材令 28 日にて行った。な押一部の供試体については, 段階 的な破壊性状を確認するために 10 ton インストロン試験機を用い て,クロスヘッドスピード $2.0 \mathrm{~mm} /$ 分で載荷し, 荷重と変位との関 係を同機のレコーダーに記録した。

\section{5 結果亡考察}

実験結果を図 5 に示す。石材の種類による耐力の違いはほとんど 見られなかった。石材の種類が同じ場合には，2 重バネ型，厚み 25 $\mathrm{mm}$, 調合 $\mathrm{A}$ の方がそれぞれハンガー型, 厚み $35 \mathrm{~mm}$, 調合 $\mathrm{B}$ に比 べて平均で 5〜10\%大きな耐力を示した。また，どの供試体も，コネ クター用穴部の初期破壊時が荷重の最大值（耐力）となったことか ら，コネクターの耐力はほとんどが石材の母材強度によって決定し たと言える。

シアコネクター引き抜き実験における荷重と変位との関係（代表 例）を図 6 に示す。この図からシアコネクターは，荷重の最大值を 示した後に引き抜けに至るまで大きな勒性を持つことがわかる。

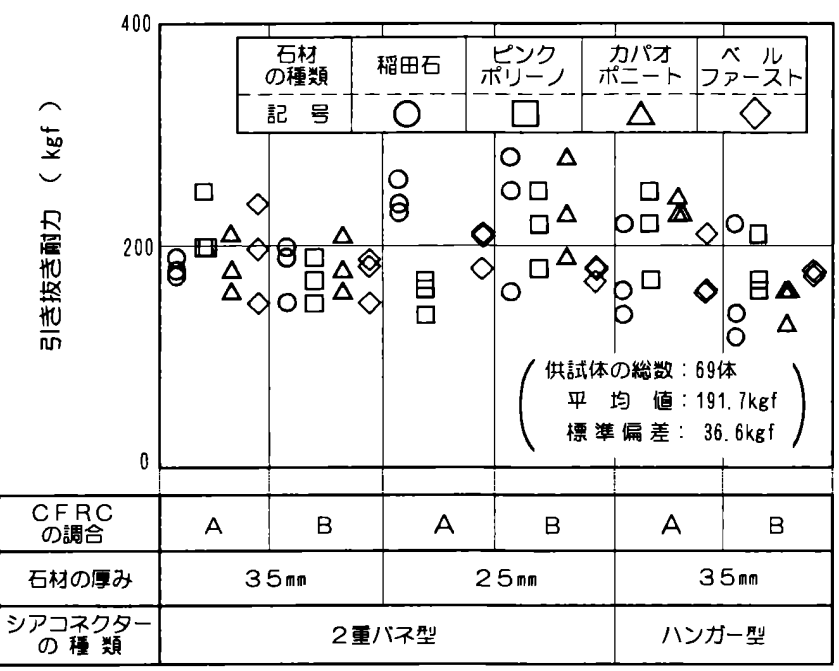

図５シアコネクター引き抜き実験結果

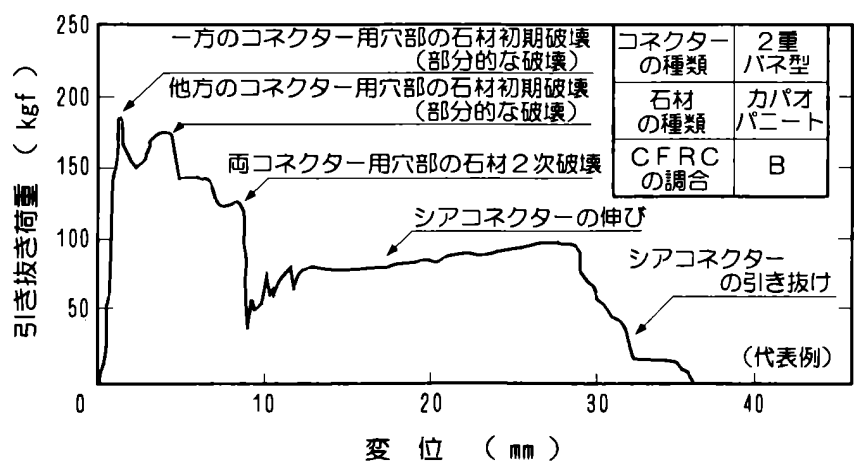

図 6 シアコネクター引き抜き実験の荷重と変位との関係

4 スチールフレーム方式 CFRC カーテンウォー ルの製造・暴露実験

4.1 実験の目的

実物大の石先付け仕上げのスチールフレーム方式 CFRC カーテ 
ンウォールを大・小 2 体製造し，製造上の問題点を洗い出し，さら に屋外暴露実験を行って反り等の観測を行い,その性状を確認した。 4.2 供試体

供試体（カーテンウォール）の形状・寸法を図 7 , 図 8 に示す。

石材の裏面は, 通常の石先付け PC (プレキャストコンクリート) カーテンウォールと同樣に，裏面処理材（弾性エポキシ樹脂）を施 しエフロレッセンス防止用の防水層をつくると共に CFRC と石材 とを絶縁し, CFRC と石材との挙動の違いによる影響を防止した。

\section{3 製造実験}

\section{3. 1 製造方法}

供試体の製造は次の手順で行った。

(1) 打設準備：型染準備, 石材配置, メッシュ敷き込み, スチール フレームの配置

(2) 打設：ホッパーにより CFRCを打設

(3) 1 次養生: 図 1 参照, 但し蒸気養生時間(最高温度保持時間) は, 供試体@：17 時間 $\left(40^{\circ} \mathrm{C}\right)$, 供試体(b)：15 時間 $\left(40^{\circ} \mathrm{C}\right)$

(4) 2 次養生：日射・通風を避けるため，材令 7 日までシート掛け

\section{3.2 結果と考察}

製造に関しては, 従来の CFRC カーテンウォールあるいは石先付 けPCカーテンウォールに関する技術でほほ対応できた。将来にお ける製造効率上の若干の課題は残ったが，特に支障となるような問 題点は見られず，実際の製造に向けての基礎デー夕を得ることがて きた。

\section{4 暴露実験}

\section{4.1 実験方法}

2 次養生後に供試体(a)，(b)を埋め込みインサート部分が支持点に なるように, 水平に並べた $\mathrm{H}$ 形鋼の上に水平に静置して屋外に暴露 した。その後, 供試体(a)は材令 6 力月，供試体(b)は材令 2 力月にて 架台に取り付け，南向きに垂直な状態でさらに暴露を続けた（写真
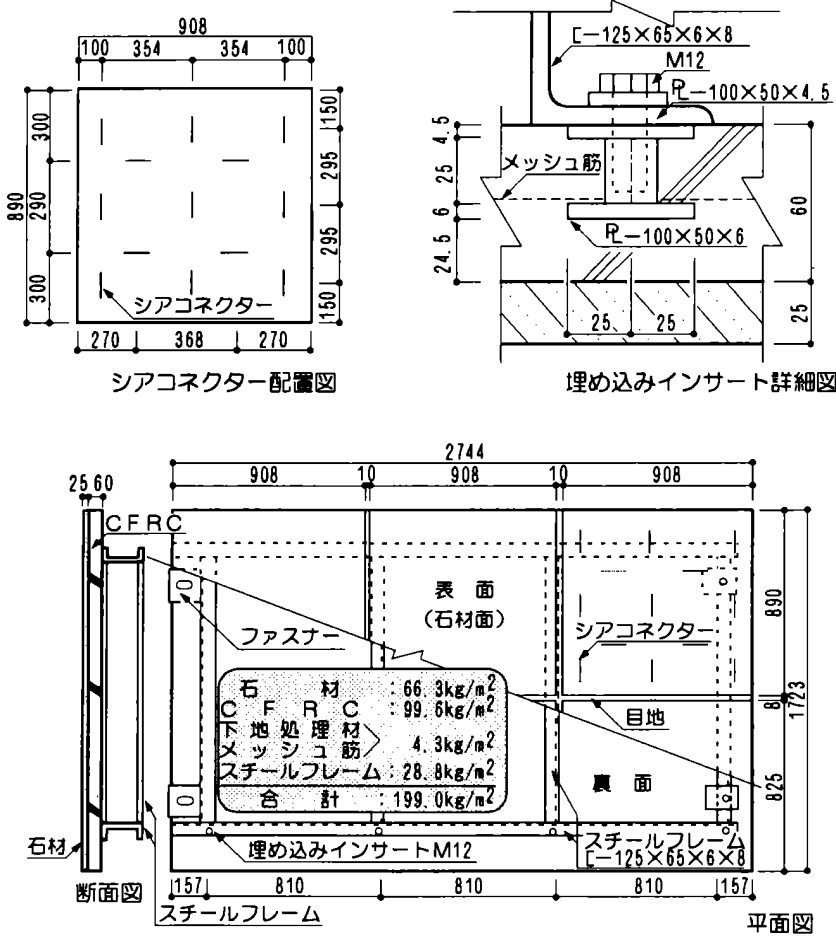

図7 供試体@の形状・寸法
1 参照)。また，所定材令にて，供試体の反りの計測及び外観の観察 を行った。なお，反りの計測は供試体の近くに設けた不動点間にピ アノ線を張り，ピアノ線と石材との間隔を測定して行った。

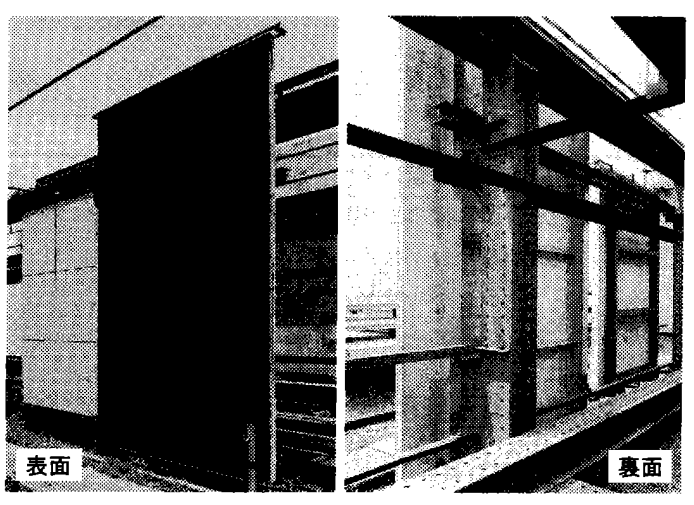

写真 1 垂直暴露状況

\section{4.2 結果と考察}

垂直暴露用の架台に取り付けた直後は, カーテンウォールファス ナーによって反りが幾分か拘束されるため，水平時よりも反りは小 さかった。

材令 1 年において, 供試体の最大変形量 $(\delta)$ は供試体(b)で 2.4 $\mathrm{mm}$ であり, 供試体長辺寸法 $(l)$ に対する変形率 $(\delta / l)$ は $1 / 1593$ と 小さかった。なお，供試体(a法が(b)より小さいため，反りはさ らに小さかった。また両供試体とも, ひびわれの発生, 石材のしみ や污れ等の異状は全く見られなかった。

今回の実験では, 両供試体ともカーテンウォールパネル端部にお ける反りは短辺方向に比べて, 長辺方向の方が小さかった。これは
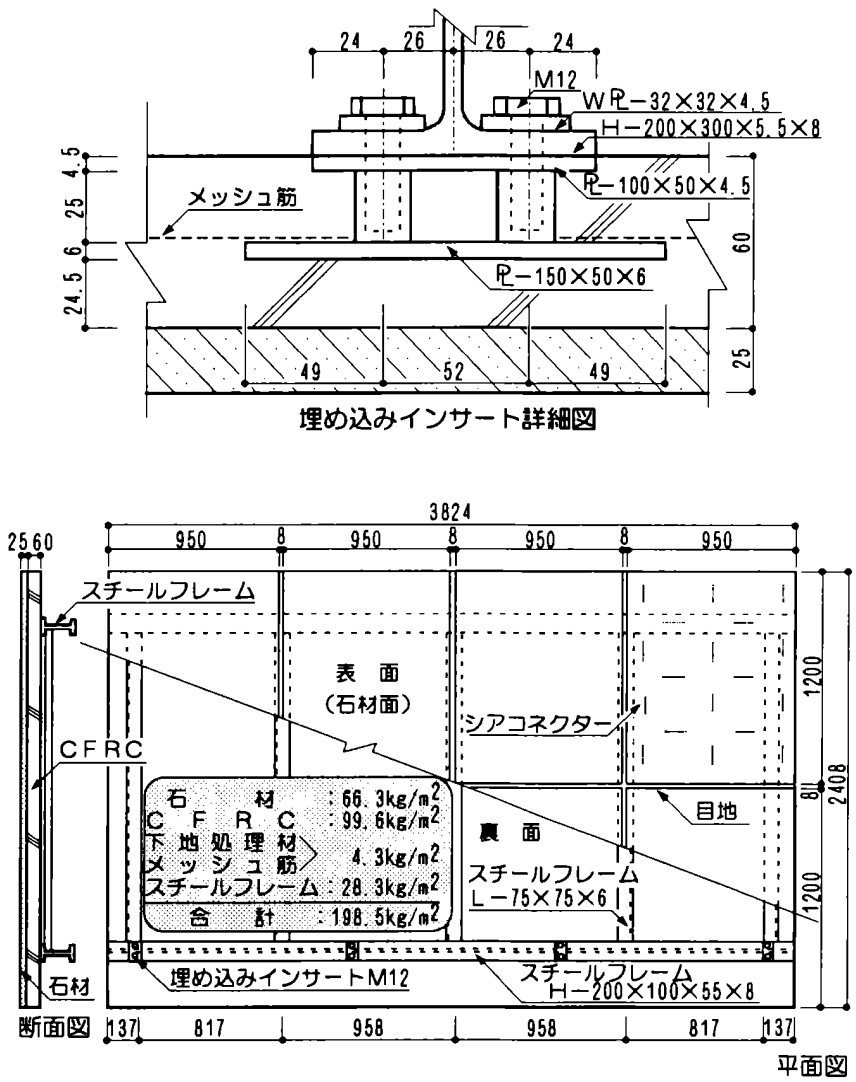

図 8 供試体(b)の形状・寸法 
長辺方向の方が埋め込みインサートの間隔が小さく，スチールフレ 一ムによる拘束が大きかったためと考えられる。したがって，短辺 方向のインサートを増設しその間隔を小さくすることによって，変 形（反り）をさらに小さくすることが可能であると推測される。

\section{5 スチールフレーム方式 CFRC カーテンウォー} ルの面外変形実験

\section{1 実験の目的}

石先付け仕上げのスチールフレーム方式 CFRC カーテンウォー ルに，風荷重を想定した等分布負圧を静的に加え，変位・ひずみ度 の測定を行い，その性能の確認を行った。

\section{2 供試体}

面外変形実験に用いた供試体は,製造実験で製作した供試体@(図 7 参照）と全く同一の仕様である。

なお,この仕様における供試体の設計風荷重 $P_{W}$ は, 建物の想定高 さを $35.7 \mathrm{~m}$ として，(1)式に示すように負圧で $440 \mathrm{kgf} / \mathrm{m}^{2}$ であ る。

$$
P_{W}=120^{4} \sqrt{35.7} \times(-1.5)=-440\left(\mathrm{kgf} / \mathrm{m}^{2}\right)
$$

\section{3 実験方法}

実験装置の概要を図 9 に示す。供試体を反カフレーム $(\mathrm{H}-300 \times$ 300)に 4 個のカーテンウォールファスナーを用いて吊り下げ，その 上部に反カフレームによって支持された底のない鋼製水槽枠（内面 ビニール袋張り)を組み立て，実験装置とした。したがって実験は， スチールフレームを除いた供試体の自重 $\left(170 \mathrm{kgf} / \mathrm{m}^{2}\right)$ が常時，供 試体に載荷された形で行った。

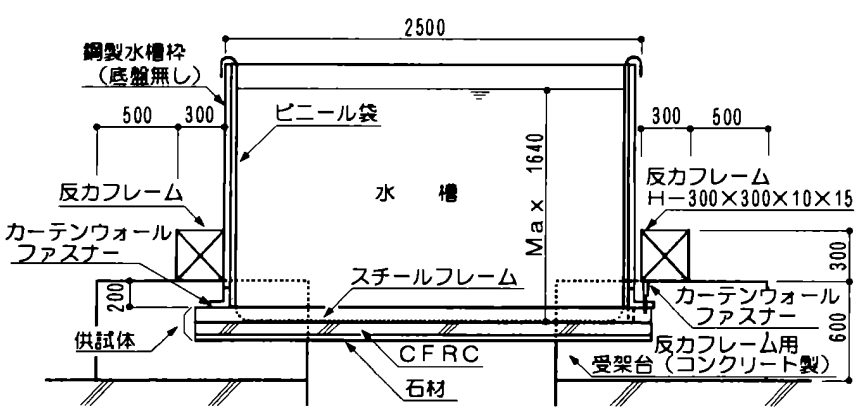

図 9 面外変形実験装置の概要

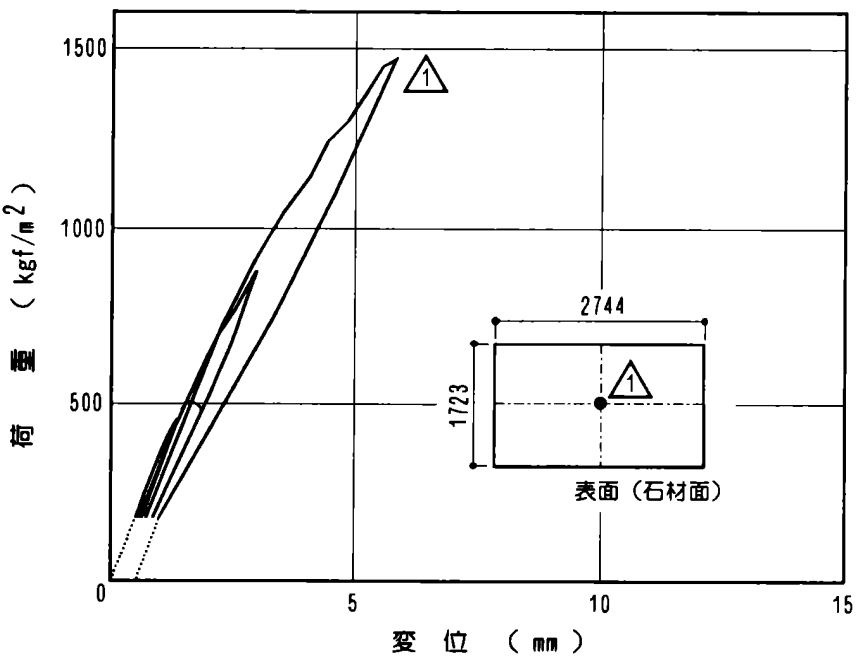

図 11 荷重と変位との関係
加力は, 供試体の CFRC の材令が 45 日のときに実施し, 水槽内 に注水し，水圧による等分布荷重によって行った。なお加力は図 10 に示すように 3 サイクルを行った。実験状況を写真 2 に示す。

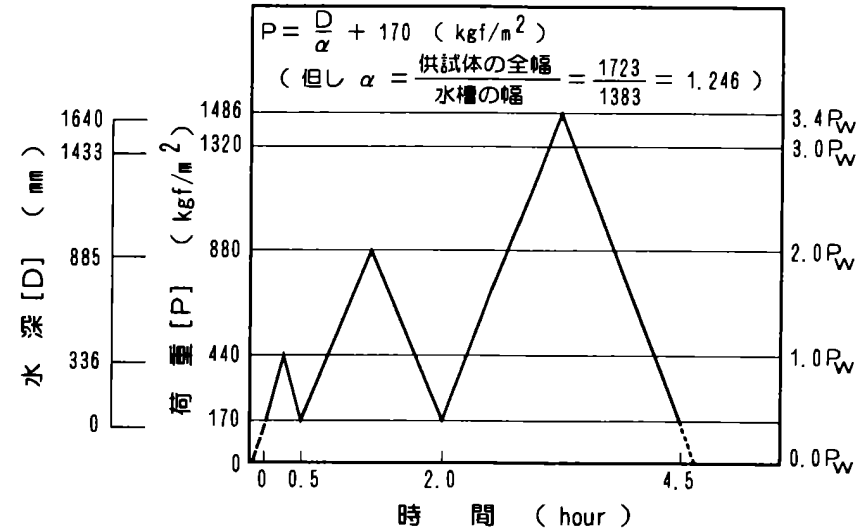

図 10 面外変形実験の加力サイクル

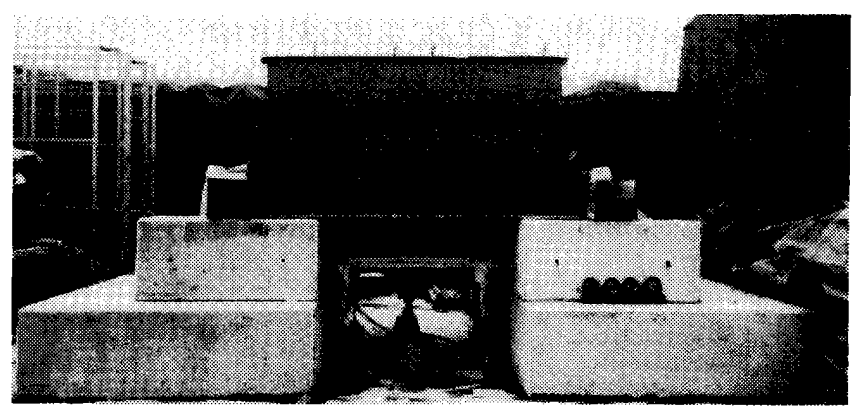

写真 2 面外変形実験

\section{4 結果と考察}

荷重と変位との関係を図 11 に示す。供試体中央部の変位は, 1.0 $P_{W}, 3.0 P_{W}, 3.4 P_{W}$ 載荷時にそれぞれ, $1.31 \mathrm{~mm}, 4.98 \mathrm{~mm}, 5.72$ $\mathrm{mm}$ だった。また，実験後の残留変位は $0.42 \mathrm{~mm}$ であり，供試体長 辺方向に対する変形率は $1 / 6533$ だった。よって供試体は, 非常に弾 性に富み，復元力が大きいという特性を示したと言える。

荷重とひずみ度との関係を図 12 に, 各材料のひずみ度を表 8 に 示す。3.4 $P_{W}$ 載荷時においても, 各材料のひずみ度は, その降伏(比

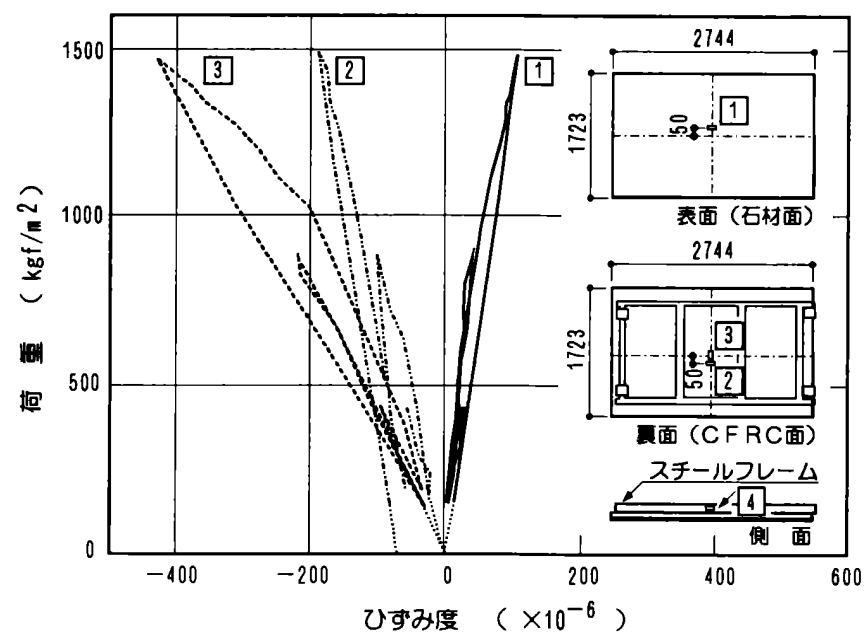

図 12 荷重とひずみ度との関係 
表 8 面外変形実験における各材料のひずみ度

\begin{tabular}{|c|c|c|c|c|c|c|c|c|}
\hline \multirow{2}{*}{ 材 料 名 } & \multirow{2}{*}{$\begin{array}{l}\text { a 降伏(比例限界)時の } \\
\text { 概略のひずみ度 }\left(\times 10^{-6}\right)\end{array}$} & \multirow{2}{*}{$\begin{array}{c}\text { 測定筒所 } \\
\text { (図 } 12 \text { 参照) }\end{array}$} & \multicolumn{3}{|c|}{ 測定值：ひずみ度 $\left(\times 10^{-6}\right)$} & \multicolumn{3}{|c|}{ 計算値 (\%) } \\
\hline & & & b 設計荷重 $\left(\mathrm{P}_{w}\right)$ 時 & c 最大荷重 $\left(3.4 \mathrm{P}_{\mathrm{W}}\right)$ 時 & d 除荷時 & $\mathrm{b} / \mathrm{a}$ & $\mathrm{c} / \mathrm{a}$ & d $/ \mathrm{a}$ \\
\hline 石材 (花崗岩) & +260 & 1 & +25 & +102 & 0 & 9.6 & 39.2 & 0.0 \\
\hline 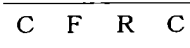 & -2000 & 2 & -57 & -186 & -58 & 2.9 & 9.3 & 2.9 \\
\hline & & 3 & -100 & -430 & -2 & 5.0 & 21.5 & 0.1 \\
\hline スチール（SS41） & -1950 & 4 & -78 & -292 & -5 & 4.0 & 15.0 & 0.3 \\
\hline
\end{tabular}

例限界）時のひずみ度に比較して十分に小さかった。

今回の実験においては，供試体の石材面（表面）ならびに CFRC 面（裏面）ともにひびわ机発生しなかった。また，石材と目地材， 及び石材と CFRC 界面での縁切れによるクラックの発生も見られ なかった。さらに, スチールフレーム, カーテンウォールファスナ 一部分，並びにインサート部分にも全く異状は認められなかった。 したがって，供試体は設計荷重に対して十分安全であると共に，設 計上，十分な余裕を持つことが確認された。

\section{6 適用事例}

低収縮セメントを用いた CFRC 及び石先付け仕上げのスチール フレーム方式 CFRC カーテンウォールについて一連の研究開発を 行い， a)CFRCの物性，b)シアコネクターの引き抜き性状，c）力ー テンウォールの製造・暴露・面外変形性能について満足なデータが 得られ，現場適用が可能であるという確信を持った。

その後, スチールフレーム方式 CFRC カーテンウォールは石材, タイル，塗装等の仕上げを施され， $\mathrm{T}$ 歯科大ビル（花崗岩先付け仕 上げ $4140 \mathrm{~m}^{2}$ )，東京都 E 博物館（フッ素樹脂塗装仕上げ 11900 $\mathrm{m}^{2}$ ), 大手町 $\mathrm{N}$ ビル (花崗岩先付け仕上げ $5300 \mathrm{~m}^{2}$ ), S ガーデンビ ル (フッ素樹脂塗装仕上げ $50000 \mathrm{~m}^{2}$ ) をはじめとして, 多くの建物 に適用されている。

なお，実際の建物に適用されていくなかで，性能の向上・コスト ダウンが図られており, 現在では, CFRCの厚みは通常は $50 \mathrm{~mm}$ で ある。また，スチールフレームや埋め込みインサートの形状にも改 良が加えられている。
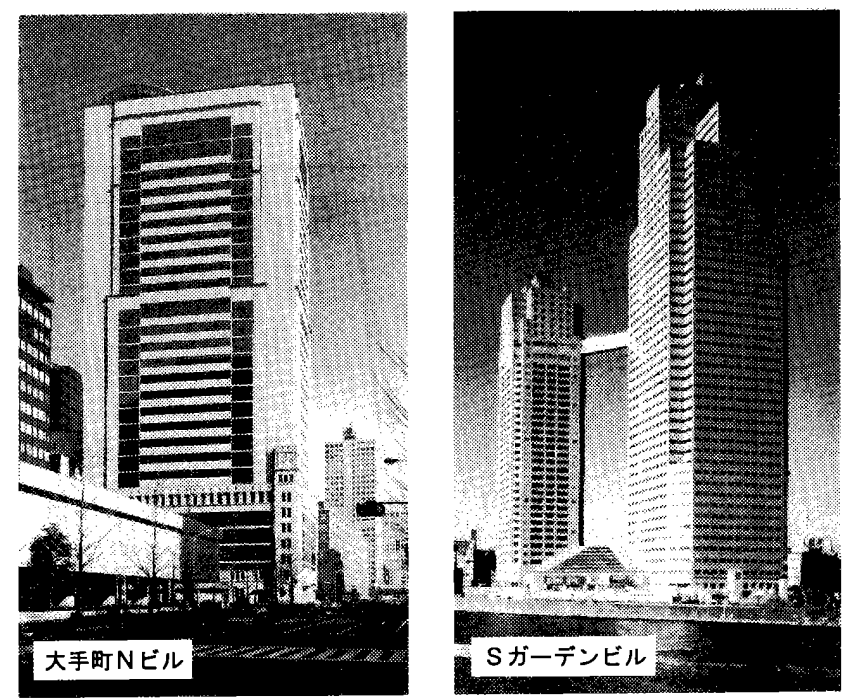

写真 3 適用事例

\section{7 今後の展開}

\section{1 高性能収縮低減材を用いた CFRC}

現在使用している低収縮セメントを用いた CFRC は, 蒸気養生が 必要である。一方, 蒸気養生が不要な高性能収縮低減材を用いた CFRCの開発を，実用化の直前まで進めている。

高性能収縮低減材は，主成分がカルシウムアルミネート系鉱物と 無機硫酸塩であり, 普通ポルトランドセメントと組み合わせて全結 合材量に対して約 $20 \%$ を混入して用いる混和材である。この混和材 を用いた CFRC は, 蒸気養生を行うことなく材令 1 日で脱型強度が 確保できる早強性がある。また, 混和材タイプのため, 遠隔地で CFRC を製造する場合に輸送上のメリットも期待できる。

\section{2 合成高分子系炭素繊維を用いた CFRC}

従来の炭素繊維とは異なり, 合成高分子系炭素繊維は瀻維直径が $30 \mu \mathrm{m}$ までの太径の繊維も製造可能である。また, 繊維の長さ・直径 の寸法精度が高い，好性が良い，繊維の製造工程がシンプルなた め繊維のコストの低減が期待できる等の特徵がある。これらの特徴 を生かして, 繊維長 $(l)$ と繊維径 $(d)$ との組み合わせの中から, 最適 なアスペクト比 $(l / d)$ を選択し，スチールフレーム方式のカーテン ウォールに適した, 流動性が良く繊維の補強効率の高い CFRCを現 在開発中である。

\section{8 おわりに}

現在でもパネルの形状や使用部位によってはリブ方式の方が適切 な場合もあり，その際はりブ方式が使用されている。ただし，製造 されている CFRC カーテンウォールの 3 分の 2 以上がスチールフ レーム方式を採用している。また現在 CFRC はカーテンウォールだ けでなく, 屋根, 軒天井, 笠木を始め建築二次部材の広い範囲で適 用が進められている。

なお，高性能収縮低減材を用いた CFRC は電気化学工業(株) と の, 合成高分子系炭素繊維を用いた CFRC は三井鉱山(株)とのそれ ぞれ共同研究によるものである。

\section{参考文献}

1）秋浜, 末永, 若山, 中川, 谷口：本石打込み CFRC（炭素繊維補強 コンクリート) カーテンウォールの開発研究（その 1), 鹿島建設 技術研究所年報, 第 36 号, pp. 47〜 54, 1988.6

2）武井, 末永, 依田：高性能収縮低減材を用いた炭素繊維補強コン クリート（CFRC）の諸特性及び水和反応機構, 鹿島建設技術研 究所年報, 第 41 号, pp. 33 38, 1993.10

3）武井，小林，末永，谷口：合成高分子系炭素繊維を用いた CFRC の特性, 鹿島建設技術研究所年報, 第 42 号, pp. 59 64, 1994.10

4）秋浜：炭素繊維補強コンクリート（CFRC）一特性と適用事例一, 建築技術, No. 412, pp. 139 148, 1985.12

[1995 年 6 月 30 日原稿受理 1995 年 8 月 25 日採用決定 $]$ 